\title{
農村移住起業者の意向にみる集積形成のメカニズム
}

一丹波篠山市福住地区を事例として一

\author{
谷川 智穂 ${ }^{1)}$ ・ 中塚 雅也 1 * $*$
}

\section{Factors and Structures of Migrant Entrepreneurship Clusters in Rural Areas: Case Study on Fukusumi District of Tambasasayama City}

\author{
Chiho Tanikawa ${ }^{1)} \&$ Masaya Nakatsuka ${ }^{1) *}$
}

This study aims to investigate the factors and structures of migrant entrepreneurship clusters and migration in Fukusumi district in Tambasasayama City, Hyogo Prefecture. Currently, an increasing number of people living in urban areas are interested in moving to rural areas. A lot of research has been conducted on entrepreneurship and settlement in these places. However, most of the studies are based on the large-scale industry accumulation and development. Additionally, not many studies have been conducted キーワード：農山村, 移住, 起業, 集積

\section{1. はじめに}

日本の農山村地域に和いて，人口減少や高齢化な ぞの問題が顕著に生じている一方で, 田園回帰と言 われるように, 若者を中心とした日本の農山村地域 への関心の高まりが指摘されている。 その中で, 移 住や起業が多数生じている地域も存在し, こうした 地域になぜ起業が多く発生するメカニズムを解明す ることは, 人材不足といった課題を抱える他地域に とっても, 移住や起業を促進するための手がかりに なる.

関連する先行研究では, 筒井他 (2015) は, 地域 の受け入れ側の視点から, 外部人材による地域のな りわいら゙くりや地域資源活用のためには, 地域と移 on comparatively small entrepreneurship in rural areas. Thus, this study investigates the case of Fukusumi, where many rural entrepreneurial activities take place. In addition, Fukusumi has one of the leading rural entrepreneurial clusters. Interview surveys were conducted in order to clarify the structure of ecosystem in Fukusumi. It was found that the people connection network is constructed, encouraging the matching of resources with migrant entrepreneurs.

住者の交流预よびサポート体制が重要であることを 指摘している. 加えて酒井他（2020）は，兵庫県丹 波市を対象に，起業補助金対象地と起業地の関係性 の存在や, 同市での起業の増加要因として, “結節 点”となる市内の支援者（知人, 親族, 民間の不動産 屋）の存在や，ICT/情報ッール活用の重要性，起業 者が支援者として活躍するような循環の存在に関し て，支援側の実態について述べている。 また，筆者 らは，岡山県西栗倉村を事例に，中山間地域に打け る起業促進について分析し, 起業者の段階に応じて, 行政が主導し官民一体の支援システムを構築してい ることを明らかにしている(中塚他，2020）。

このように，農山村の起業を促進する環境につい

\footnotetext{
1) 神戸大学大学院農学研究科; Graduate School of Agriculture, Kobe University

*E-mail: nakatsuka@port.kobe-u.ac.jp

( )地域農林経済学会
} 
ては, 受け入れ側に求められる要点の整理が進んで いる。しかしながら, 農山村地域での移住起業者（利 用者）の起業地の選択については分析されていない. 関連するものとして, 望月（2018）が広島県尾道市 を事例に，その集積メカニズムを分析しているが， 地方都市部に扮けるプロジェクト先導型のもので農 山村には援用困難な点が多い, 農山村地域において は，土田（2020）は，北海:道東川町の飲食店を事例 に, 起業行動と起業の進展要因として, 農村思考や 家族・親類の存在, 小規模経営志向といった起業者 の内的要因や, 同町の自然環境, 都市や空港に近接 寸る立地条件や，サポート人材の存在といった外的 要因の作用を明らかにしている.

これに従らと，農山村地域，中でも特に，条件不 利地域や過疎地域と言われるよらな交通の便が悪い 地域では，起業の集積が生じることはないと考えら れるが，実際には，そらした地域も起業地として選 ばれていることが全国で散見される。しかしながら， ぞのような場所が選ばれ，起業が生じているのかは そのメカニズムは明らかでない。

そこで, 本研究では, 兵庫県丹波篠山市福住地区 を事例地域として分析を試みた。 同地は, 農山村地 域の中でも中心部から遠く, 過疎地であり交通の便 が悪い地域であるが，近年移住者による起業が相次 いでいる. 福住地区については, 中塚 $(2013,2018)$ が空き家活用の展開について分析し，アクターが新 たなアクターを獲得していることや, 利用希望者(移 住者）と集落内部と空き家改修を行う専門家の 3 つ のネットワークとその八ブとなるコーディネーター の存在の機能を指摘しているが，これらもあくまで 地区で展開する事象の整理と受け入れ側や支援側の 視点分析に基づくものであり, なぜこの地区を選ぶ かいら移住起業者視点の分析はなされていない.

以上より，本稿に沶いては同地区に打ける移住起 業者に対してインタビュ一調査を行い，この地域を 選択した理由や移住起業に至った経緯, 地域資源等 との関連性を分析することにより，集積が形成され たメカニズムを明らかにすることを目的とした。

\section{2. 対象と調査方法}

(1) 研究対象

丹波篠山市は兵庫県の中東部に位置し, 京都府や
大阪府と隣接している農山村地域である。丹波篠山 市（2019）によると，面積は，377.59km² であり， 2019 年 9 月末現在の人口は 41,395 人である. 人口 は， 2045 年には， 2015 年の $68 \%$ まで減少すると推 計されて扣り，全国平均が $83.7 \%$ であることから， 過疎化が比較的進行している地域と言える（国立社 会保障・人口問題研究所，2018）。一方で，2018 年 には 1,334 人の転出があるものの，1,345人が市内に 転入して打り，市外からの人の動きが見られる。市 の中央部に位置する中心市街地および，西部に通る JR 福知山線との間のエリアは比較的市街地が存在す るが，市の北部や東部，周辺部に沶いては山地や農 地から成る中山間地域が広がっている.

福住地区は，市の最東部に位置し，東は京都府， 南は大阪府と隣接して和り, 京都拈よび大阪の中心 部より，車で 1 時間程の立地にある。地区の中心部 は, 京都につながる街道沿いの宿場町として栄光, 2012 年には当時の篠山市福住伝統的建造物群保存 地区（宿場町・農村集落の町並夕）に指定され，現 在でも宿場町の街並みが残っている. 丹波篠山市は, 19 の旧小学校区（2015 年時点）があり，小学校区 を基本に 19 の「まちづくり協議会」（地域運営組 織）が設立されている. 福住地区も，2007 年に「福 住地区まちづくり協議会」を立ち上げ，地区単位で の地域づくり活動を行っている. 2019 年 9 月現在 で，19 集落，608 世带，1,306 人である（丹波篠山 市，2019）. 2009 年 9 月時点での 642 世帯， 1,633 人 と比べて大きく減少し，2016 年春に福住小学校も閉 校したが，地元住民や移住者との協働で跡地を活用 する動きや，街道沿いの新しい店舗のオープンなど， 新たな動きが生じている.

\section{（2）調査方法}

本研究では, 福住地区に打怕移住起業者を対象 に，同地区を選択した理由や経緯について対面によ るインタビュ一調査を実施した．対象事業者の起業 地については，福住地区の場合に限定したが，居住 地については，丹波篠山市内に移住した場合を対象 にした．ただし，1名（1 事業者）のみ，生活の事情 から一時的に市外飞居住して和り，市外から通って いるケースがあったが，対象に含めた．

調査は，福住地区まちづくり協議会の協力を得て おこなった，具体的には，まず同地区の移住者のう 
ち，事業を行ら者の一覧および起業年のデータを協 議会の担当者から入手した. 一覧にある 31 名に書面 でインタビューの依頼したところ, 計 16 名に対して 調査を実施することができた，このうち，12 名 6 組 が夫婦で同一の事業を運営していたため, 対象事業 者数は 10 件であった.

それぞれのインタビュ一時間は 60 分程度で, 福住 地区内の各事業所にて実施した。実施期間は，2020 年 9 月であった.

インタビューは，あらかじめ，地域選択の要素と して各種経営資源, 人的ネットワーク, 生活環境な ぞを想定しつつも, 調査対象の起業者に移住起業の 経緯を時系列で自由に会話を促寸非構造的な方法を とった.

\section{3. 結果}

\section{（1）福住地区の起業の概要}

まず，同地区の移住起業者の概要を示す，福住地 区内の移住起業は，2011 年以降に発生して预り， 2020 年 9 月末までに全 18 件が発生している. 表 1 に示すように, 前半の 2011 年 2015 年の起業は 4 件に対し, 後半の 2016 年 2020 年の起業は 13 件で あり，近年増加している，このらち，今回インタ ビューを実施することができた事業所の内訳は，表 1 括弧内の, 対象事業所数倸寸通りである. 今回 インタビューを実施した 10 事業者のらち市内在住者 は (夫婦で実施している場合は 2 人とも), すべて他
表 1. 福住地区内の移住起業事業所数

(単位 : 件)

\begin{tabular}{cc}
\hline \hline 起業年 & 全事業所数 (対象事業所数) \\
\hline 2011 年 & $1(1)$ \\
2012 年 & $2(1)$ \\
2013 年 & $1(0)$ \\
2014 年 & $1(1)$ \\
2015 年 & $0(0)$ \\
2016 年 & $1(1)$ \\
2017 年 & $3(1)$ \\
2018 年 & $2(1)$ \\
2019 年 & $3(2)$ \\
2020 年 & $4(2)$ \\
\hline 計 & $18(10)$ \\
\hline
\end{tabular}

資料：地区担当者整理の一覧表から筆者作成.

地域出身者であるIターン移住であった。な抏，同 地区の移住起業者による事業に打いて，2020 年時点 で廃業は 0 件であるが， 2013 年開業の 1 件は現在, 休業中である.

表 2 は, 対象事業者の概要と事業規模として, 開 始年，事業規模について示したものである。事業内 容としては，飲食業が 3 件，ゲスト八ウスが 2 件, 生活雑貨の小売等を行う事業所が 2 件，その他 Web 製作，デザイン業，写真家が 1 件ずつであり，個人 客を対象とした小売やサービス業が多く占める．従 業員数はどの事業者も $1 \sim 3$ 名であり，2 名の事業者 は全て，夫婦で運営している。

表 2. 対象事業者の概要と事業規模

\begin{tabular}{cccccc}
\hline \hline 事業者 & 事業内容 & 事業開始年 1$)$ & 従業員数 & 年間売上規模 & 商圏 (市外: 市内) \\
\hline A & イタリア料理 & 2011 & 2 人 & $100 \sim 500$ 万円未満 & $8 \sim 9: 1 \sim 2$ \\
B & ゲストハウス & 2012 & 2 人 & $100 \sim 500$ 万円未満 & $9: 1$ \\
C & Web 製作/移住空口等 & 2014 & 3 人 & $1,000 \sim 5,000$ 万円未満 & $9: 1$ \\
D & 珈琲豆焙煎/カフェ & 2017 & 3 人 & $1,000 \sim 5,000$ 万円未満 & $7: 3$ \\
E & 生活雑貨販売/美容 & 2018 & 1 人 & 100 万円未満 & $8: 2$ \\
F & 生活雑貨製作/販売 & 2019 & 2 人 & $100 \sim 500$ 万円未満 & $9: 1$ \\
G & デザイン & 2019 & 1 人 & $1,000 \sim 5,000$ 万円未満 & $9: 1$ \\
H & ゲストハウス & 2019 & 2 人 & 100 万円未満 & $10: 0$ \\
I & パン屋 & 2020 & 2 人 & 500 万円 1000 万円未満 & 不明 \\
J & 芸術写真家 & 2020 & 2 人 & N/A & $10: 0^{2)}$ \\
\hline
\end{tabular}

資料：ヒアリング調査より筆者作成．表 $3 \sim 5$ も同様である。

1）福住地区内で事業を開始した年.

2) 移転直後の数值となる. 
表 3. 移住起業の目的と移住候補地 - 先住地 - 居住地

\begin{tabular}{|c|c|c|c|c|c|}
\hline 事業者 & 移住起業の目的 & 移住起業候補地 & 先住地 & 居住地 & $\begin{array}{l}\mathrm{I} / \mathrm{U} \\
\text { ターン }\end{array}$ \\
\hline A & 広い場所で事業を実施するため & 明確に定めていなかった & 神戸市 & 福住内*1) & I \\
\hline $\mathrm{B}$ & ゲストハウスを実施するため & 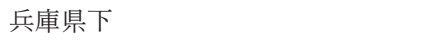 & 兵庫県西宮市 & 市外 & I \\
\hline $\mathrm{C}$ & 田舎で，地域 PR の仕事をするため & 明確に定めていなかった & 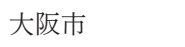 & 福住内 & I \\
\hline $\mathrm{D}$ & 広い焙煎所を構えるため & 大阪から 1 時間圏 & 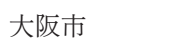 & 市内 & I \\
\hline $\mathrm{E}$ & 自身の事業を実施するため & 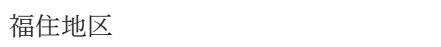 & 福島県白河市 & 福住内 & I \\
\hline $\mathrm{F}$ & 子どもの子育て環境を変えるため & 明確に定めていなかった & 丹波篠山市 & 福住内* & I \\
\hline G & 農村地域で居住し, 事務所を構えるため & 丹波篠山市内 & 大阪府茨木市 & 市内 & I \\
\hline $\mathrm{H}$ & ゲストハウスを実施するため & 丹波市周辺かつ阪神圏から 1 時間圏 & $\begin{array}{l}\text { 兵庫県芦屋市/ } \\
\text { 丹波市 }\end{array}$ & 福住内* & I \\
\hline I & パン屋を開くため & 明確に定めていなかった & 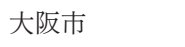 & 福住内* & I \\
\hline $\mathrm{J}$ & ギャラリーや写真の暗室を構えるため & 関西圏 ～～～～～～～～～ & 神戸市 & 市内 & I \\
\hline
\end{tabular}

1）事業所と住居が同一物件の場合は「*」を付記.

年間の売上規模においては, 100 万円未満が 2 件, 100 500 万円未満が 3 件, 500 万円 1,000 万円未 満が 1 件, 1,000 5,000 万円未満が 3 件, 時期によっ て変動があるためわからないが 1 件であった. 各事 業所の商圏としては, ほとんどの事業者が $1 \sim 3$ 割程 度は, 市内に顧客を抱えているが, 主な商圏は市外 であった。

次いで, 移住起業の目的扎よび, 移住候補地・先 住地・居住地などの居住地の移動に関する情報を示 したものが表 3 である. 移住起業の目的については, 住まいが地区内にある場合も含め，事業を実施する ことを目的に移住してきたと回答した事業者が注と んどであった。

移住候補地は, 関西圏, 阪神圏から 1 時間圏, 明 確に定めていなかった，といった，広い地域を対象 にしていた事業者が多く, 丹波篠山市や福住地区を 対象に探していた事業者は，それぞれ1件ずつであっ た.

福住に移住する前の居住地（先住地）は, 8 事業 者が京阪神からの移住であり, 先住地が丹波篠山市 である事業者に打いても，4 年前に大阪府豊能郡よ り移住している，福住地区内に居住地を置いている 事業者が 6 件, このらち, 事業所と住居が同一の物 件であるのは 4 件であった.

\section{（2）移住起業において求めていた条件}

表 4 に, インタビュ一の結果を基に, 事業者が移 住起業に颃いて求めていた条件をまとめた。 インタ
ビューの回答を分析すると，物件に関して，店舗が できる物件や事業に適した広さの物件といった,「事 業に適する物件」といら要素や，農村的な風景や子 育て環境，伝建地区のまちなみといった「自然・農 村的環境」が抽出された，中でも，「事業に適する物 件」は，11事業者中 10 業者が回答していた.

また，ある程度の街があり，人の流れがあるとこ ろや，逆にポッンと一軒家といった「人や物がある こと」「周囲に何もないこと」といった，相反する条 件が抽出された。これは，2017年までに事業を開始 した $\mathrm{D}$ 事業者までと， $\mathrm{E}$ 以降の事業者で傾向が分か れているとも言える.

表 5 には, 移住起業経緯の中で挙げられた, サポー 卜を受けた仲介者についてまとめた。最も多いのが 移住起業者による仲介であったが，ほとんどの場合 に打いて，複数分類の仲介者により 2 段階の仲介を 受けていた。 また，前半と後半の移住起業者で仲介 者が異なり, 最初の A，Bについては市内のまちつ くり・空き家活用の団体（ $\mathrm{N}$ 社）より情報を得てい たが，それ以降では，移住起業者から $\mathrm{N}$ 社（または その逆), GやI に打いては, 移住起業者が地元住民 への繋ぎ役を果たしていた，最後のJについては， 自身で地元住民の運営による同小学校活用団体の HP より情報を得えていた。な报，E，F， G，Hの 仲介役として挙がった移住起業者は, 事業の一つと して移住相談空口も始めた C 社であった. 
表 4. 移住起業に拈いて求めていた条件

\begin{tabular}{|c|c|c|c|c|}
\hline 事業者 & & 求めていy & こ条件 & \\
\hline A & 店舗ができる広い物件 & 農村的な風景 & - & $\begin{array}{l}\text { ポツンと一軒家のような, } \\
\text { 何もないところ }\end{array}$ \\
\hline $\mathrm{B}$ & ゲストハウスができる物件 & 伝建地区のまちなみ & - & - \\
\hline $\mathrm{C}$ & - & - & - & $\begin{array}{l}\text { ひとりあたりの空間が広 } \\
\text { い場所 }\end{array}$ \\
\hline $\mathrm{D}$ & $\begin{array}{l}\text { コーヒー豆の焙煎ができる広 } \\
\text { い物件 }\end{array}$ & - & - & $\begin{array}{l}\text { ポツンと一軒家のような, } \\
\text { 何もないところ }\end{array}$ \\
\hline $\mathrm{E}$ & 店舗に適した物件があった & - & - & - \\
\hline $\mathrm{F}$ & 店舗ができる物件 & 田舎的な子育て環境 & - & - \\
\hline G & $\begin{array}{l}\text { 自宅に近い場所で事務所を構 } \\
\text { える物件 }\end{array}$ & - & $\begin{array}{l}\text { ある程度の街があり, 人の } \\
\text { 流れがあるところ }\end{array}$ & - \\
\hline $\mathrm{H}$ & ゲストハウスができる物件 & - & $\begin{array}{l}\text { 周りにコンテンツがあると } \\
\text { ころ }\end{array}$ & - \\
\hline I & パン屋ができる物件 & 山と里地のバランスがよい & - & - \\
\hline $\mathrm{J}$ & $\begin{array}{l}\text { 展示ギャラリーが設置できる } \\
\text { 広いスペースのある物件 }\end{array}$ & 自然があるところ & - & - \\
\hline $\begin{array}{l}\text { 抽出 } \\
\text { 要素 }\end{array}$ & 事業に適する物件 & 自然・農村的環境 & 人や物があること & 周囲に何もないこと \\
\hline
\end{tabular}

表 5. 移住起業の仲介者

\begin{tabular}{|c|c|c|c|c|}
\hline 事業者 & 行政 & $\begin{array}{c}\text { 市内の } \\
\text { 団体 }\end{array}$ & $\begin{array}{c}\text { 移住 } \\
\text { 起業者 }\end{array}$ & $\begin{array}{l}\text { 地元 } \\
\text { 住民 }\end{array}$ \\
\hline A & - & $\rightarrow 1)$ & & \\
\hline B & 4 & -0 & & \\
\hline $\mathrm{C}$ & & O & $\rightarrow$ & \\
\hline $\mathrm{D}$ & & & $\rightarrow$ & \\
\hline $\mathrm{E}$ & & $\leftarrow$ & & \\
\hline$F$ & & & 4 & \\
\hline $\mathrm{G}$ & & & 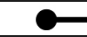 & $\rightarrow$ \\
\hline $\mathrm{H}$ & & & 0 & \\
\hline I & & & & \\
\hline $\mathrm{J}$ & & & & 0 \\
\hline
\end{tabular}

1） 1 段階目， \2 2 段階目の仲介者を示す，2）Dの 又 2 組の移住起業者の支援を受けている.

\section{4. 考察}

以上の結果から, 移住起業者の集積が進むメカ二 ズムについて考察を行ら.

まず，事例地の移住起業者は，表 2 に示すように, 飲食店や雑貨店など顧客が直接足を運ぶ形態の事業 者が主であり，多くは市外にマーケットを持ってい ることが分かった，また，地域選択については，表 3 に示した移住起業の目的と候補地からわかるよう に，全体として事業実施を目的としつつも，当初の 候補地は広範囲にわたって扣り，更に，表 4 にある
ような「事業に適する物件」「自然・農村的環境」「人 や物があること」「周囲に何もないこと」というよう な条件に合致する候補地を探していた。しかし，こ らした地域は，広域で見たときには福住地区以外の 場所にも存在する。 その中でも同地区が選択された 理由は，物件と移住希望者をマッチングする仕組み が存在していることであると考えられる。これは事 業を始めるには，必要不可欠なことでもあるが，農 村地域ではそらした環境が整っていないことが多く，

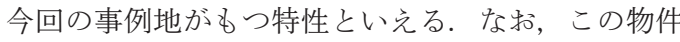
とのマッチングの仕組みは，表 5 で示したと拉り， 前半から後半にかけてから徐々に変化していること も分かった。

続いて移住起業者の集積が進んだメカニズムにつ いて考察を行う. 表 3,4 より前半の移住起業者は, 集積のない“何もない田舎”を期待して移住してきて いるが，後半は，ある程度，起業集積のある，福住 地区の今後に期待感を抱いた事業者が移住してきて いるといら傾向にある. 後半で移住起業者が集積し た背景として，地元の受け入れ体制が強化されたこ とはあるが, 移住起業者の求める条件にも変化が生 じていることが明らかになった.

図 1 は, 事例地区での移住起業者の集積のメカ二 ズムを改めて整理したものである。まず，移住起業 


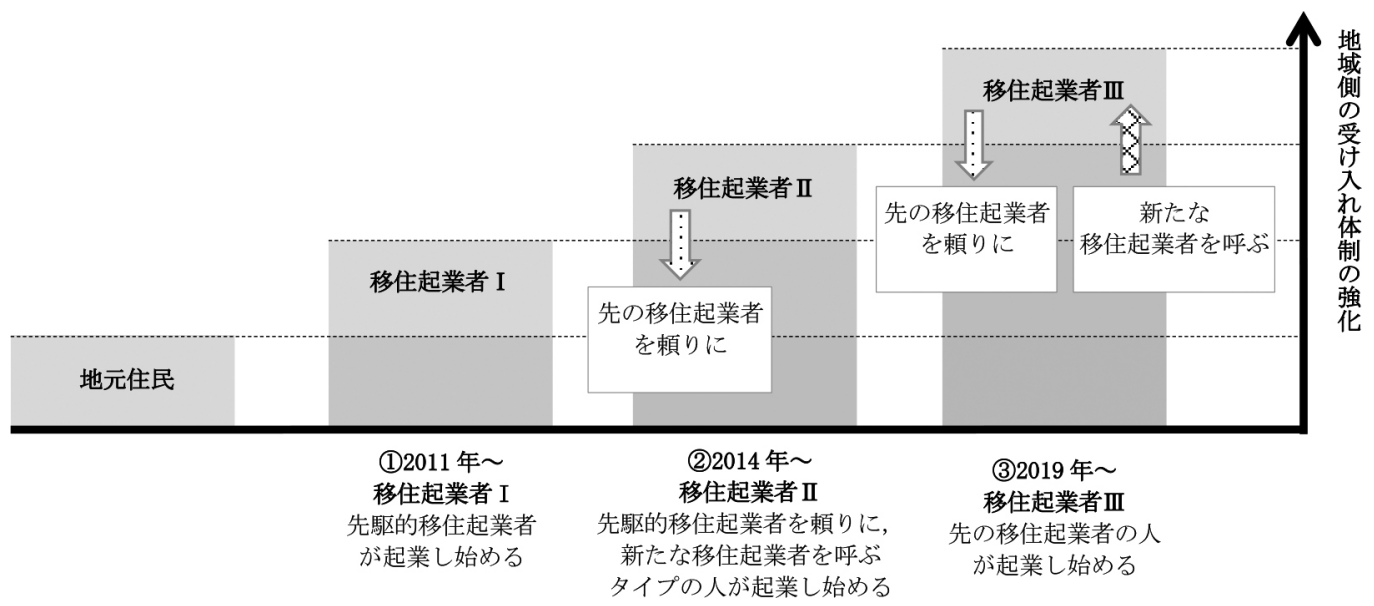

図1. 移住起業者の集積のプロセス

資料 : 筆者作成.

者を I 〜 IIIの 3 タイプに分類し，同時に，それらの 移住起業者タイプが入り始めた時期を(1)〜 (3)の 3 時 期に分け，横軸に示した。 (1)では，集積が少ない場 所に, 先駆的移住起業者 I が入り, (2)では, 移住起 業者 I の情報を基に，まだまだ集積が少ない土地に， 新たな移住起業者を呼ぶタイプの移住起業者凹が入 りはじめ, (3)では, 移住起業者 I, IIがいる場所に, ある程度の仲間や集積を求めてきた移住起業者亚が 入り始めた. 縦軸には，(1)，(2)，(3)の時期に移住起 業者が蓄積していくことにより，地域側の受け入れ 体制の強化が生じたことを示している.

以上のことを踏まえると，集積のメカニズムは， 1）何もないことを望む人が移住し，2）移住起業者 が増えることで，移住起業者を含む“地域”の受け入 れの体制が強化され，3）その中で, 受け入れを積極 的に呼び込み，手引きする人が現れることで，受入 れ体制が更に強化され，4）ある程度の集積を求める 人が集まってくる，5）更に集積が進む，という連鎖 のプロセスとして整理することができる.

\section{5. おわりに}

以上，本論では，農山村に括ける移住起業者の立 地選択理由および集積との関連性について議論して きた。

結果は, 地域のアクターとネットワーク（中塚, 2013）や，受け入れ側の環境整備や PR 活動（土田,
2020）といった既往研究で示された要点を，移住起 業者側の視点から補完したものであるが，その中で も事業物件へのアクセスが重要であることを新たに 確認した。また，移住起業者が地元の受け入れ体制 の強化に寄与寸ること, 移住起業者のタイプ（地域 に求める条件）を変えながら集積が進むことを明ら かにした。

こらした集積のメカニズムは，事業者数の規模か ら，望月（2018）の事例のようなプロジェクト先導 型のダイナミックな集積とは異なるが，農山村地域 に打ける一つの移住起業の集積メカニズムを示した ものといえる.

なお，本論は，大都市から 1 時間程度の距離にあ る場所にある伝建地区を事例とした分析である．異 なる環境条件にある農山村地域においても同様の集 積が起こりえるのか，といった点など，結果の一般 化や妥当性向上については，今後の課題としたい．

\section{引用文献}

国立社会保障 ・人口問題研究所（2018）「日本の地域別将来推 計人口（平成 $30(2018 ）$ 年推計」, http://www.ipss.go.jp/ppshicyoson/j/shicyoson18/t-page.asp（2020.10.5 参照）。

酒井扶美・立見淳哉・筒井一伸（2020）「農山村に打ける移住 起業のサポート実態一兵庫県丹波市を事例として一」『Ejournal GEO』15(1) : $14-28$. https://doi.org/10.4157/ ejgeo.15.14.

丹波篠山市 (2019)「2019（令和元）年度版丹波篠山市統計書」, 
https://www.city.tambasasayama.lg.jp/material/files/ group/50/102jinkou.pdf (2020.10.5 参照).

土田慎一郎 (2020)「北海道東川町に和ける移住起業の進展要 因 : 飲食店の移住起業に着目して」『地理学論集』95(1)： 1-11. https://doi.org/10.7886/hgs.

筒井一伸・佐久間康富・嵩 和雄（2015）「都市から農山村一 の移住と地域再生一移住者の起業・継業の視点から一」『農 村計画学会誌』34(1)：45-50。 https://doi.org/10.2750/ arp.34.45.

中塚雅也 (2013)「アクターとしての再生民家と地域ネットワー ク一兵庫県篠山市福住地区を事例として一」『農村計画学
会誌』32(2)：113-116. https://doi.org/10.2750/arp.32.113.

中塚雅也（2018）「集落に打ける空き家活用とその展開構造」 中塚雅也編著『地域固有性の発現による農業・農村の創 造』筑波書房 : 173-183.

中塚雅也・谷川智穂・井筒耕平（2020）「中山間地域に打ける 起業促進の支援システム一岡山県西粟倉村を事例として」 『農村計画学会誌』39(論文特集号) : 113-116.

望月 徹（2018）「尾道中心市街地への若い移住者集積のメカ ニズム: 一商都 850 年の歴史・伝統・文化を継承するヒュー マンスケールのまちづくり一」『日本国際観光学会論文集』 25(0) : 69-83. https://doi.org/10.24526/jafit.25.0_69. 